\title{
THE EFFECT OF DIFFERENTIATED LEARNING METHOD ON STUDENTS' ACHIEVEMENT IN WRITING SKILLS IN LEARNING ARABIC AS A FOREIGN LANGUAGE
}

Najiba Abdullah Meyad ${ }^{1}$, Samsilah Roslan ${ }^{1}$, Maria Chong Abdullah ${ }^{1}$, Pabiyah HajiMaming ${ }^{2}$

1.Faculty of Educational Studies, University Putra Malaysia, 43400 Serdang, Selangor, Malaysia najabdullah@yahoo.com, samsilah@educ.upm.edu.my, maria@educ.upm.edu.my 2.Faculty of Modern Language, University Putra Malaysia, 43400 Serdang, Selangor, Malaysia

pabiyah@upm.edu.my

\section{ABSTRACT}

Differentiated Learning is a method of teaching which has been set and used in education to meet learners' various needs and preferences. This paper investigates the effect of Differentiated learning method (DLM) on students' achievement in writing skills in learning Arabic as a foreign language in Malaysia. A total of 100 students (47 males and 53 females), who were randomly selected, participated in this study. The pre-and post-tests comparison groups design was used to determine if there was significant differences between the experimental and control groups. The experimental group was taught using DLM, while the control group was taught using the teacher-centered method (TCM). Descriptive statistics were used to determine the effect of DLM on students' achievement in writing skills. The statistical results demonstrated that there was a significant difference in the post-test between the experimental group $(M=10.14, S D=2.79)$ and the control group ( $M=8.20$, $\mathrm{SD}=2.38) ; \mathrm{t}(3.73), \mathrm{p}<.05)$. The experimental group's achievement was generally more than the control group's which proves that the DLM is an effective approach in improving students' writing achievement in learning Arabic Language as a foreign language in Malaysia.

\section{Keywords}

Differentiated Learning Method, Achievement, Writing Skills, and Arabic Language.

\section{Academic Discipline and Sub-Disciplines}

Education and Psychology; Teaching and learning

\section{SUBJECT CLASSIFICATION}

Discuss about using differentiated learning method in writing Arabic language as a foreign language in Malaysia secondary school form four.

\section{TYPE (METHOD/APPROACH)}

Experimental study; pre-and post-Tests.

\section{Council for Innovative Research}

\author{
Journal: International Journal Of Research In Education Methodology
}

Vol. 6, No. 2

www.ijrem.com , ijremeditor@gmail.com 


\section{INTRODUCTION}

Teaching and learning Arabic language in Malaysia is very important particularly for the Muslim Malays in order to perform their prayers and religion [1, 2]. According to some researches $[3,4,5,6,7]$ the performance of the students in Arabic language is still very poor. They struggle and face challenges while studying Arabic language especially the writing skills. In fact, Arabic language is rich in grammatical structures and complex vocabulary conjugation that make it even more challenging to be taught and learned; and a lot of learners regardless of being native or non-native speakers see it as a challenging subject to be learned $[8,9,10,11]$. In addition, Arabic writing system, which is very essential to the establishment of automatic word recognition, represents a major obstacle for native speakers and that can be even more difficult for nonnative speakers [9, 11]. Abdul-Hamed [4] found that Malaysian students faced a problem in applying the Arabic writing rules and unique characteristics such as using and applying of Al-Hamz'a while writing. A lot of students, particularly non-native speakers, encounter difficulties and get confused whenever they write a word that contains AI-HAMZA [4, 12]. Furthermore, Arabic language has some letters and vocabularies that sound similar and that results in having difficulties while learning AL's skills for non-native speakers particularly when it comes to dictation. The students tend to make a lot of mistakes when they try to write the words they hear particularly those students who do not practice a lot and feel bored in Arabic language class $[12,13]$.

Teaching Arabic language needs appropriate way to capture students' interest during teaching and learning Arabic writing skills otherwise the performance of students will deteriorate [1, 4,5]; and some researchers mentioned that using appropriate method in teaching Arabic has a positive impact on students' motivation and achievement compared to using conventional method of teaching $[4,5,17,18,19,20,7]$. Using appropriate method will not only motivate students towards studying but will also help them to achieve their maximum growth [21].

Some teachers wonder why some students face a lot of difficulties in learning while others tend to learn faster. Consequently, some teachers might believe the problem lies within the students themselves whereby the problem might be emerged from the curriculum or the method being used in teaching $[14,15,16]$. Some teachers tend to not be aware of students' diversity in the classroom. In fact, for ensuring the students are performing equally, a proper way of teaching method should be used. A method that meets student's needs and addresses the differences among the students within the class.

\section{DIFFERENTIATED LEARNING METHOD}

Differentiated method has been used in learning process as flexible method that can be tailored to help diverse students to achieve better based on their needs. Differentiated method is used to take care of the diversity of learners in one classroom [22]. According to Tomlinson [21] one way of delivering information does not fit all the students' needs in one class due to the fact that the students vary in needs, personal interest, performance level, gender, and learning style. The teacher should be aware of these varieties during planning the method of teaching in the classroom and ensure differentiation to respond to students' needs [21, 23]. As a result, in 2001, differentiated learning approach was adopted and practiced in schools due to the "No Child Left Behind (NCLB)" legislation [24, 25, 26]. Adopting the method to be used into teaching and learning process always comes after recognizing the nature of the students' interest, readiness, needs, and the school's environment and the facilities [27].

However, teaching to middle way of teaching to reach each student in the class is not effective. It does not augur well to the needs of intelligence students, often leaving them unchallenged and bored. Also it ignores and confuses lower students who face a lot of problems during learning [16, 21, 28, 29].

Differentiated Instruction is a theoretical framework that aims to increase flexibility for all learners, so each student gets equal opportunities to learn effectively [30]. The idea behind using differentiated is that students learn at different ways and they find certain type and level of tasks and assignments more challenging and interesting [21, 31]. Differentiated learning is used to respond to different level of students' readiness. The advantage of using differentiated learning method allows students to work with tasks that challenge them. It also empower students to choose the best way to show others what they know and how they want to demonstrate their understanding based on their learning style and preferences [31].

In addition, differentiated instruction concerns on differentiation to increase flexibility in learning by facilitating access of materials in an effective way and based on students' differences and learning styles. Also, it works on minimizing the barriers that frequently limit students' access to materials during learning in the class room [32].

\section{DIFFERENTIATED LEARNING ELEMENTS}

According to Tomlinson [24] there are three elements which can be differentiated during teaching and learning to meet students' interests, needs and learning preferences: differentiated content, differentiated process, and differentiated product. Figure 1 shows the elements of differentiated learning used in this study for teaching writing skills in AL. 


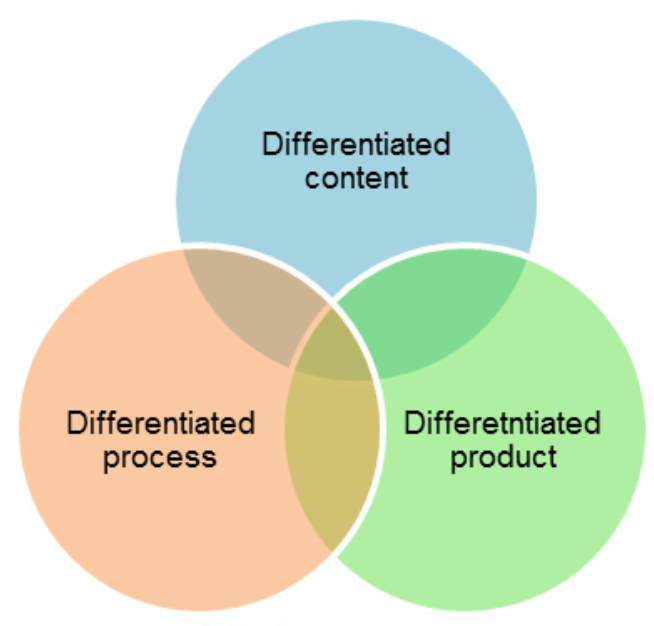

Fig1: Elements of DLM

Differentiated content refers to providing learners with a variety of materials and activities to support differentiated content. Selecting activities and writing topics are very important in DLM because this selection should be based on learners' needs, interest, and readiness level. Providing learners with multiple options during learning will not only help them to finish their tasks, it also helps them to increase their motivation and achievement level to understand the concept and skills [21, 24, 33]. For instance, in writing AL, the teacher should provide the learners with various writing topics and activities for students to choose from; also students will have permission to come up with their own new topic which they prefer to write about based on their interests and needs.

Differentiated process refers to how the concept is taught using different way of teaching and divers activities to help learners to understand the concept in an interesting way based on their needs. In DLM students can work individually, in pairs, in groups, or work with whole class with the teacher. Also the teachers in DLM should teach under different condition and places such as cold place, warm place, in the class, library or in the playground [34, 35]. So the learners can choose the place which they like and prefer to set and come up with their writing.

Differentiated product means that providing the learners with variety of assessment strategies and performance in order to master the content. Learners should demonstrate their knowledge and come up with their idea based on their choices and preferences [32, 34]. Learners in secondary school, form four level, should learn how to write a paragraph or an essay in Arabic language as well as how to use the punctuation in their writing. In this case learners can choose any topic they prefer to write about. This choice can be differentiated by content; choose any topic or any assignment based on learners choices and differentiated by the level of performance $(A, B, C)$. For example, for level of performance, the learner who is good in writing and has a lot of vocabularies in Arabic language can write an essay starting from the third level (C). And the learners who are average can start by second level (B) with writing some paragraph. But the learners who just learn how to write and do not have a lot of vocabularies in Arabic language can start with first level (A) with writing some sentences to explain anything based on their interest and choice. Figure 2 presents the level of performance $(A, B, \& C)$ in writing.

Furthermore, learners have permission to start from $A$ to $C$ based on their readiness and choice but the teacher should be aware of the students who are weak and need support from them to pass from first level to the other [25].

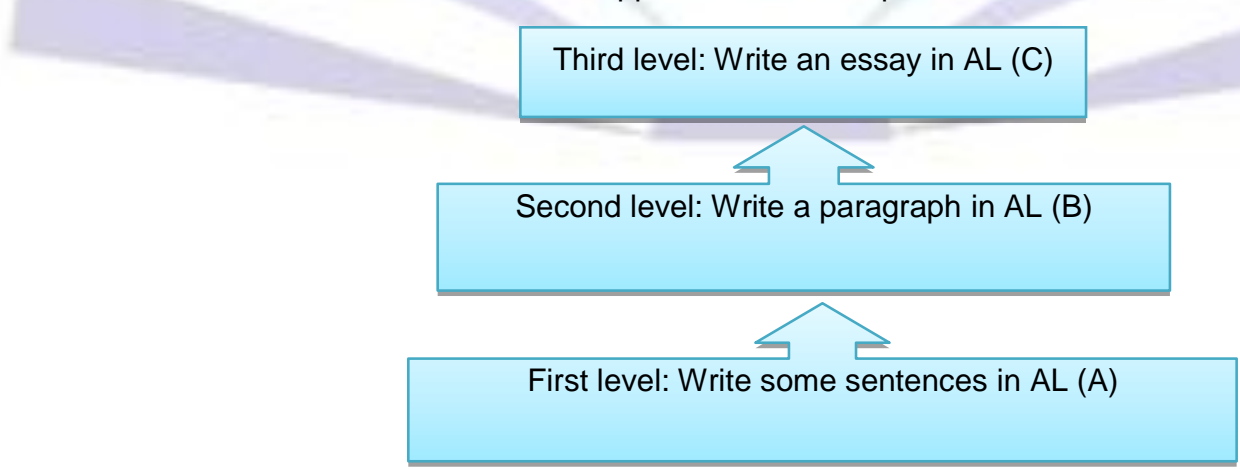

Fig 2: Differentiated Levels of writing skills in AL

\section{METHOD AND DESIGN}

A quasi- experimental quantitative research design has been employed in this study to examine the effect of DLM on students' achievement in writing skills in Arabic language as a foreign language in Malaysia. Two intact groups were randomly selected and assigned randomly to the experimental and control groups. Table 1 illustrates the study design. 
Table 1. Pre-test and Post-test Control Design

\begin{tabular}{|l|l|l|l|}
\hline Groups & Pre-test & Treatment & Post-test \\
\hline Experimental & $\mathrm{O}_{1}$ & $\mathrm{X}_{1}$ & $\mathrm{O}_{2}$ \\
Control & $\mathrm{O}_{1}$ & $\mathrm{X}_{2}$ & $\mathrm{O}_{2}$ \\
\hline
\end{tabular}

Note:

O1 = Pre-test to examine students' writing achievement in Arabic.

$\mathrm{O} 2$ = Post-test to examine students' writing achievement in Arabic.

$\mathrm{X} 1$ = Differentiated Learning Method (DLM) for the experimental group only

X2 = Teacher-Centered Method (TCM) for control group only.

\section{Participants}

The participants in this study were form four students attending secondary school in Kolej Islam Sultan Alam Shah (KISAS) in Klang, Malaysia. The sample for this study was a cluster random sample of four intact classes selected from among the 12 form four classes using a fish bowl technique. After that, a random assignment was applied to select which classes belong to the control group and which classes were in the experimental group. The control group had 50 participants (24 males and 26 females) and the experimental group had 50 participants, 23 males and 27 females. All the students were Malays and in the same age group.

\section{INSTRUMENTS}

The data was collected using instrumental achievement test which was prepared by some of the teachers who teach Arabic language for non-native speakers in form-four secondary school Selangor Malaysia coordinated by the researcher. The achievement test was to measure the writing skills in AL. The students were asked to write a paragraph to measure their skills in writing and grammar. The test has been checked for face and content validities thoroughly by experts in the domain. Also the reliability of the instrument has been checked and the Cronbach's alpha value was found to be acceptable.

\section{RESULTS}

In order to determine the effect of DLM on students' writing skills achievement in Arabic language, the scores were analyzed. A comparison analysis was done to compare the differences between the means scores of the experimental and control groups before and after the intervention by using paired sample t-test and one-way ANCOVA.

\section{Paired Sample t-test}

To evaluate the effectiveness of DLM, on students' improvement from the pre-test to the post-test in one group, a paired sample t-test was used to compare between the mean scores in the experimental group before and after intervention. The finding revealed that there was a significant difference between the pre-test and post-test in writing achievement for the experimental group. Table 2 presents the result.

Table 2. paired sample t-test for pre and post-test in writing achievement for experimental group

\begin{tabular}{|l|l|l|l|l|l|}
\hline Test & Mean & S.D & df & $\boldsymbol{t}$ & $\boldsymbol{p}$ \\
Pre-test & 7.24 & 1.95 & & & \\
Post-test & 10.14 & 2.79 & 49 & -8.42 & $.000^{*}$ \\
\hline
\end{tabular}

${ }^{*} p<.05$

According to Table 2 above, there was a significant difference in the mean scores of writing achievement between the pretest $(M=7.24, S D=1.95)$ and post-test $(M=10.14, S D=2.79), t(-8.42) ; p<.05)$ in the experimental group. The DLM had an effect in improving the students' achievement in writing skills.

\section{One-Way ANCOVA}

In order to assess whether the experimental group had higher achievement in writing than the control group, a one-way between groups analysis of covariance was used to reduce the statistical error. It is statistically recommended to use ANCOVA in the pre-test and post-test research designs [36]. ANCOVA was used to reduce the statistical errors caused by the correlation co-efficient between the pre-test and the post-test. The pre-test scores were used as the covariate variable and a comparison was made between the control and experimental groups using a one-way of ANCOVA procedure.

ANCOVA was used to compare the mean scores in writing between the experimental and control groups and the results shown that there were significant differences in the scores for the experimental $(M=10.14, S D=2.79)$ and control groups $(M=8.20, S D=2.38 ; p=.000)$. Table 3 below presents the mean scores for control and experimental groups in writing achievement. 
Table 3. Means for post-test between experimental and control group in writing Achievement.

\begin{tabular}{|c|c|c|c|}
\hline Groups & N & $\boldsymbol{M}$ & S.D \\
\hline Experimental & 50 & 10.14 & 2.79 \\
\hline Control & 50 & 8.20 & 2.38 \\
\hline
\end{tabular}

The findings from the table above revealed that the means score for experimental group were higher than the mean score for the control group

Furthermore, the pre-test scores were used as the covariate, and a comparison was made between the groups (controls \& experimental) using one way ANCOVA. Table 4 shows the result.

Table 4. One-way ANCOVA for the post-test scores as a function of groups, using pre-test as a covariate in the writing achievement.

\begin{tabular}{|c|c|c|c|c|c|}
\hline Source & $\mathbf{d f}$ & Mean Square & $\mathbf{F}$ & Sig. & Partial Eta Squared \\
\hline Pre-test & 1 & 214.70 & 46.55 & $.000^{*}$ & .32 \\
\hline Groups & 1 & 64.68 & 14.02 & $.000^{*}$ & .12 \\
\hline Error & 97 & 4.61 & & & \\
\hline${ }^{*} p<.05$ &
\end{tabular}

Based on the table above the results show that there are significant differences between the experimental and control groups in the post-test after controlling the pre-test, $F(1.97)=14.02, p=.000$. In addition, the finding from one-way analysis of ANCOVA indicates that the DLM was effective in improving the students' writing achievement in Arabic language as a foreign language. The writing mean score for the DLM experimental group was higher than the mean scores for the TCM control group writing. There was a significant difference between the two groups at a level of significant .05 .

In addition, the effect size as indicated by the corresponding partial eta squared value is .12, and it is considered to be a large effect size according to Cohen's [37] guidelines; there is a difference in the achievement in writing scores obtained before and after the intervention.

\section{DISCUSSION}

According to the findings, the DLM had some effects on the students' achievement. Students using DLM in learning writing skills achieved better than students using the teacher-centered method. This results can be explained by Tomlinson's model of Differentiated Instruction [21, 24] and Kelly's curriculum theory [38] as they mentioned that teaching with planning (content, process, and product) while recognizing students' differences, and continuous guidance are very vital in teaching and learning process.

In addition, having a teaching method that makes students to take in information in an easy way and based on their needs results in high achievements; and, consequently makes teaching and learning more effective and successful [34, 39]. So, when students have chance to choose the topic which they are going to write about, they will be more motivated and succeed more. But if the teacher forces students to write about a topic that they do not have any idea and they are not interested in that topic, they will be less interested and their performance will be weak and low [21, 25].

Similarly, students learn best when they relate what is in the curriculum with their interests and experiences, and this can be one of the reasons behind the significantly positive effect of DLM on students' achievement in writing skills. DLM moves students to understand the information and uses different ways of teaching and presenting information in a wide range of activities based on students' preferences, abilities and interests [25, 39, 40]. Adjusting and providing students with multiple options of writing topic based on their interests encourage students to understand better and make sense of the concept of the subject efficiently $[35,41]$.

Moreover, realizing and making relationship between the needs of students and the value of the subject during teaching and learning Arabic language, as it is the language of the holy Quran, increases students' motivation and achievement [1, $18,42]$. Interests and values play vital role in learning because values combined with expectancy equals motivation and achievement. In the contrary, when students do not value of what they are learning, they might get motivated which results in poor achievement [43].

The findings of this study were in line with some researches [22,28,44] which have the same result; learning using differentiated increases students' performance compared to traditional teaching method.

\section{CONCLUSION}

The findings of this study indicate that the DLM improves students' writing achievement in learning Arabic language as a foreign language for Malaysian secondary school students. The finding proved that using differentiated learning in Arabic language has a positive impact on students' achievement. Students who were taught using DLM performed better than those taught using teacher-centered method. DLM helped form four secondary school's students in Malaysia to learn better while providing them with multiple options of different topics in writing based on their choices and interest. DL 
supports the needs of diverse students in one classroom. Finally, this study indicates that using DLM has a positive effect and it can be used in teaching and learning Arabic writing skills.

\section{REFERENCES}

[1] Hawatemeh, A. H. R. (2000). Factors influencing the effectiveness of teaching Arabic as a foreign language at the federal government Islamic higher secondary school in the State Of Selangor Darul Ehsan, Malaysia. (Unpublished master dissertation), International Islamic University Malaysia (IIUM).

[2] Haron, S. C., Ahmad, I. S., Mamat, A., \& Mohamed, I. H. A. (2010). Understanding Arabic-speaking skill learning strategies among selected Malay learners: A case-study at the International Islamic University Malaysia (IIUM). Contemporary Issues in Education Research (CIER), 3(8), 9-20.

[3] Dahab, M. I. (1999). Evaluation of the Arabic Language integrated curriculum for Secondary Schools (KBSM). (Unpublished PhD dissertation), Universiti Kebangsaan Malaysia (UKM).

[4] Abdul-Hamed, K. R. (2004). Effect of cooperative learning on achievements in Arabic writing and social skills for form two students in Selangor, Malaysia. (Unpublished doctoral dissertation) University Putra Malaysia (UPM).

[5] Yaakub, M. B. H. (2007). Teaching Arabic as a second language: An evaluation of key word method effectiveness. Jurnal Teknologi 46(1): 61-72. Universiti Teknologi Malaysia.

[6] Samah, R. (2012). Proceedings from PKEBAR '12 UKM National Conference on Teaching and Learning Arabic: Issues of Learning Arabic Language.

[7] Awang, N. A., Mohamed, M. H., \& Sulaiman, R. (2013). Enhancing Arabic Speaking Skills among Malay Students through Group Work Activities. International Journal of Humanities and Social Science, 3.

[8] Abdullah. S. (1996). Problems of teaching Arabic Language at Government Religious School in Province of AchehIndonesia. (Unpublished master dissertation) International Islamic University (IIUM).

[9] Abdullah, A. M. (2005). The problem of learning Arabic Language in secondary school in Nigeria. (Unpublished doctoral dissertation) University of King Saud, Education Faculty.

[10] AL-Hasmy, H. A. (2006) The Role of Educational Supervisors in Developing Teaching Skills: The Perception of Arabic language in Riyadh, Kingdom of Saudi Arabia. (Unpublished master dissertation) International Islamic University Malaysia (IIUM).

[11] Hansen, G. F. (2010). Word Recognition in Arabic as a Foreign Language. The Modern Language Journal, 94(4), 567-581

[12] Ismail, m. R., \& Pa, M. T. (2006). Introduction to the linguistic juxtaposition between the Malaysia language and Arabic language. Pengajaran Dan Pembelajaran Bahasa Arab di Malaysia (1 ed., pp. 111, 145). Kuala Lumpur: Penerbit University Malaya.

[13] Madkour, A. A. (2010). Strategies of teaching Arabic Language. (2 ed.). Kuala Lumpur, Malaysia Daru Almasirah p102.

[14] Jonassen, D. H., \& Grabowski, B. L. H. (1993). Handbook of individual differences, learning, and instruction. London: Lawrence Erlbaum Associates Publishers.

[15] Hitchcock, C., Meyer, A., Rose, D., \& Jackson. R. (2002). "Providing new access to the general curriculum universal design for learning." Teaching Exceptional Children 35(2): 8-17.

[16] Wlodkowski, R. (2011). Enhancing adult motivation to learn: $A$ comprehensive guide for teaching all adults. $3^{\text {th }}$ ed. San Francisco, CA: Jossey-Bass publishers, Inc.

[17] Mustapha, N. F. b. (2011). Reading Strategies and the Related Impact on Students' Reading Comprehension among Arabic Students in Putra Malaysia College Knowledge and Humanities Sciences. (Unpublished PhD dissertation). International Islamic University Malaysia IIUM

[18] Zainuddin, N., \& Sahrir, M. S. (2011) Steps and Procedures of Teaching Writing Skill via Wiki Among Learners of Arabic as Second Language as a Model. Journal of Linguistic and Literary Studies.IIUM. ISSN 2180-1665 (In Press).

[19] Haron, S. C. (2012). The Teaching Methodology of Arabic Speaking Skills: Learners' Perspectives. International Education Studies, 6(2), p55.

[20] Alkhasawneh, S. (2013). The Effect of Web-Based Teaching On Female Jordanian Basic School Students' Arabic Language Reading Comprehension Achievement And Motivation. (Unpublished PhD dissertation). UPM.

[21] Tomlinson, C. A. (2000). Differentiation of Instruction in the Elementary Grades, ERIC Digest. ERIC Clearinghouse on Elementary and Early Childhood Education ED443572.

[22] Muthomi, M. W. and Z. K. Mbugua (2014). "Effectiveness of Differentiated Instruction on Secondary School Students Achievement in Mathematics." International Journal of Applied 4(1). 
[23] Lawrence-Brown, D (2004). "Differentiated Instruction: Inclusive Strategies For Standards- Based Learning That Benefit The Whole Class". American Secondary Education 32 (3): 34-62.

[24] Tomlinson, C. A. (2001). How to differentiate instruction in mixed-ability classrooms. (2 ${ }^{\text {nd }}$ ed) Beauregard USA: (ASCD) Association for Supervision \& Curriculum Development.

[25] Northey, S., (2005). Handbook on differentiated instruction for middle and high schools. New York, NY 10017: Eye on Education.

[26] Subban, P. (2006). Differentiated instruction: A research basis. International Education Journal, 7(7), 935-947

[27] Tomlinson, C. A. (2008). Mapping a Route toward Differentiated Instruction. Educational Leadership, 57: $12-17$.

[28] Koeze, P. A. (2007). Differentiated instruction: the effect on students' achievement in an elementary school. (Unpublished PhD dissertation), Eastern Michigan University. Digital Commons @ EMU1-1

[29] Van Tassel-Baska, J. (2012). A Teacher's Guide To Differentiating Instruction. "Sahled". Better Education Better Life. Retrieved on September 2013 from: http://www.sahledu.com/sm/A-Teacher\%E2\%80\%99s-Guide-to-DifferentiatingInstruction/MzE=

[30] Rose, D., \& Meyer, A. (2002). Teaching every student in the digital age: Universal design for learning. Retrived on 26 Desember from http://www.cast.org/teachingeverystudent/ideas/tes/

[31] Little, C. A., Hauser, S., Corbishley, J. (2009). "Constructing Complexity for Differentiated Learning." Mathematics Teaching in the Middle School 15(1): 34-42.

[32] Hall, T., Strangman, N., \& Meyer, A. (2003). Differentiated instruction and implications for UDL implementation. Wakefield, MA: National Center on Accessing the General Curriculum. No. H324H990004

[33] Van Tassel-Baska, J. (2003). Differentiating the language arts for high ability learners, K-8. ERIC Digest. Arlington, VA: ERIC Clearinghouse on Disabilities and Gifted Education. (ERIC Document No. ED 474306) Retrieved August 18,2014 , from

[34] Tomlinson, C. A., Brighton, C., Hertberg, H., Callahan, C. M., Moon, T. R., Brimijoin, K., et al. (2003). Differentiating instruction in response to student readiness, interest, and learning profile in academically diverse classrooms: $A$ review of literature. Journal for the Education of the Gifted, 27(2/3), 119-145.

[35] Good, M. E. (2006). Differentiated Instruction: Principles and Techniques for the Elementary Grades. (Unpublished Master dissertation). University of California. WorldCat.

[36] Pallant, J. (2005). SPSS survival manual: A step by step guide to data analysis using SPSS. (12 ed) Australia: ALLEN \& UNWIN. Open University Press.

[37] Cohen, J. (1988). Statistical power analysis for the behavioral sciences. Second Edition. Hillsdale, NJ: Lawrence Erlbaum Associates Publishers.

[38] Kelly, A. V. (1977-2009). The curriculum: Theory and practice. $6^{\text {th }}$ ed. London: SAGE

[39] Smith, P. C. (2006). The Effects of Technology-Integrated Differentiated Instruction on Language Arts Achievement. Retrieved October 29, 2010 from http://chiron.valdosta.edu/are/vol5no2/ PDF/AREarticlesVol5no2/SmithP. AREarticle- vol5no2.pdf

[40] King-Shaver, B., \& Hunter, A. (2003). Differentiated instruction in the English classroom. USA: Portsmouth, NH: Heinemann.

[41] Tomlinson, C. A., Disabilities, E. C. O., \& Education, G. (1995). Differentiating instruction for advanced learners in the mixed-ability middle school classroom: ERIC Clearinghouse on Disabilities and Gifted Education, the Council for Exceptional Children. (ERIC ED389141)

[42] Wigfield, A., \& Eccles, J. S. (2000). Expectancy-value theory of achievement motivation. Contemporary educational psychology, 25(1), 68-81.

[43] Feather, N.T. (1982) Expectations and Actions: Expectancy-Value Models in Psychology. Hillsdale, New Jersey: Lawrence Erlbaum Associates.

[44] Kadum-Bošnjak, S. \& Buršić-Križanac, B. (2012). "IMPACT OF DIFFERENTIATED INSTRUCTION ON ACHIEVEMENT IN TEACHING MATHEMATICS TO LOWER-STAGE GRADES." Metodički obzori 7(15): 15-29. 